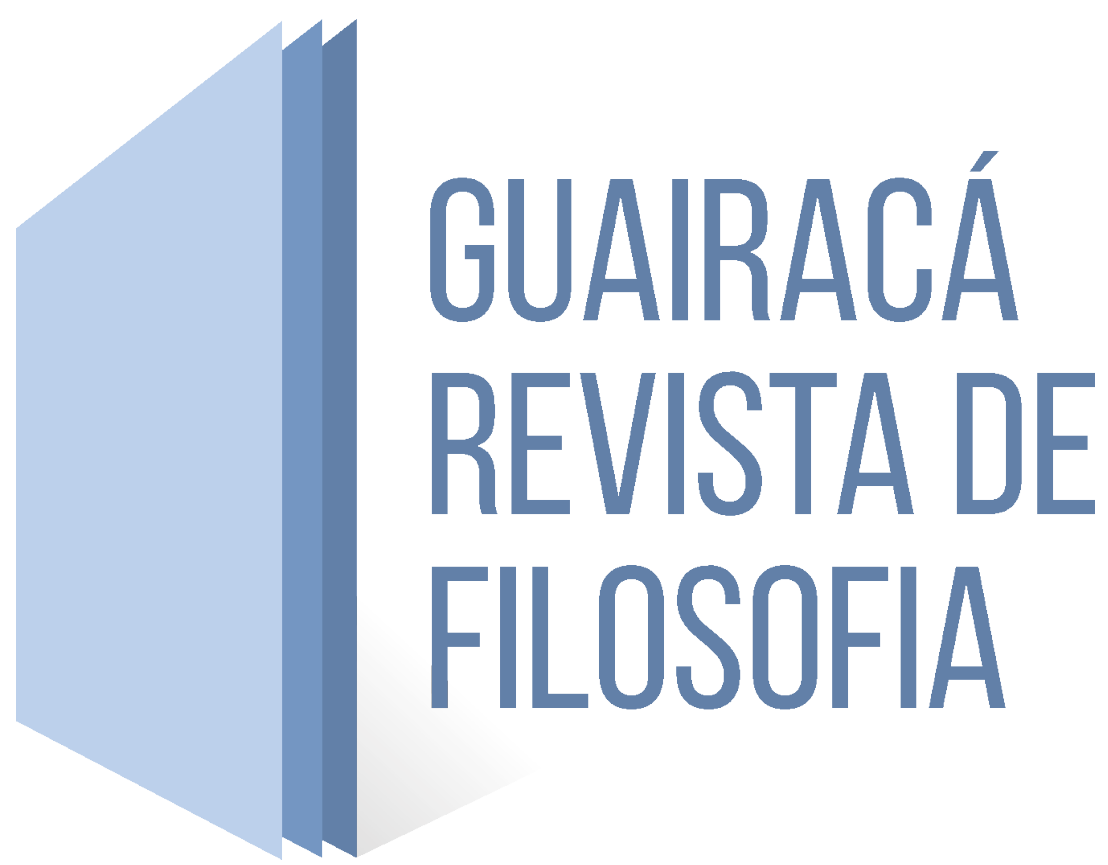

\title{
EDUCAÇÃO E FORMAÇÃO DE BOÉCIO: FONTES OCULTAS DA BÍBLIA EM SUA CONSOLAÇÃO
}

\section{CLEBERDUARTE COELHO'}

Resumo: Buscaremos, neste artigo, indicar alguns aspectos gerais a respeito de um dos mais importantes filósofos do período patrístico, a saber: Severino Boécio. De modo mais específico, buscaremos nos ater ao fato de Boécio em sua obra mais famosa, $A$ Consolação da Filosofia, não fazer uma única citação da Bíblia. O diálogo estabelecido entre o sábio romano e sua musa consoladora, a Filosofia, não faz nenhuma referência ao Livro Sagrado, mas possui fontes ocultas do mesmo, como procuramos demonstrar.

Palavras-chave: Formação. Bíblia. Consolação.

\section{EDUCATION AND FORMATION OF BOETHUS: HIDDEN SOURCES OF THE BIBLE IN HIS CONSOLATION}

Abstract: In this article we will try to indicate some general aspects about one of the most important philosophers of the patristic period, namely Severino Boethius. More specifically, we will seek to draw attention to the fact that Boethius in his most

1. Doutor em Filosofia pela UFSC. Professor de filosofia da UFSC. E-mail: rebelc2000@yahoo.com.br. 
famous work, The Consolation of Philosophy, does not make a single quotation from the Bible. The dialogue established between the Roman sage and his comforting muse, Philosophy, makes no reference to the Holy Book, but has hidden sources of it, as we have tried to demonstrate.

Keywords: Formation. Bible. Consolation.

Buscaremos, neste breve apontamento, indicar alguns aspectos gerais a respeito de um dos mais importantes filósofos do período patrístico, a saber: Severino Boécio. De modo mais específico, buscaremos nos ater ao fato de que Boécio em sua obra mais famosa, A Consolação da Filosofia (De Consolatione Philosophiae, doravante $D C P$ ), não fazer uma única citação da Bíblia. O diálogo estabelecido entre o sábio romano e sua musa consoladora, a Filosofia, não faz nenhuma referência ao Livro Sagrado. No entanto, referências a filósofos como Sócrates, Platão e Sêneca são frequentes, nesta obra singular de um filósofo que se vê diante da morte e discorre sobre temas tais como: falsos bens da Fortuna, felicidade, a existência do mal no mundo, onisciência divina e livre-arbítrio. Deste modo, o tema sobre o qual discorreremos aqui não será voltado para a exegese dos principais conceitos tratados por Boécio em sua Consolação, mas sim, uma análise das fontes ocultas e/ou implícitas do Livro Sagrado pertencentes à sua obra do cárcere. Estas fontes ocultas da Bíblia na Consolação, como buscaremos demonstrar, foram fundamentais para que o sábio romano encontrasse seu caminho de retorno à verdadeira morada. Neste sentido, os conceitos que investigaremos na Consolação nos servirão de subsídio ao propósito maior deste artigo: as fontes ocultas da Bíblia no DCP de Severino Boécio.

Severino Boécio (480-524) possui grandioso valor para a Filosofia, não apenas como autor, mas também como tradutor de alguns pensadores que o antecederam. Foi grande filólogo e erudito. Gilson (2001,p. 161) nos diz que "sua intenção inicial era traduzir todos os tratados de Aristóteles, todos os diálogos de Platão e demonstrar por comentários a concordância fundamental de suas doutrinas". Boécio foi um convicto cristão que, inclusive, envolveu-se no debate com heresias da época, havendo redigido cinco pequenos tratados teológicos até hoje tidos como modelo de trabalho racional em defesa da fé. Executado por suspeita de traição ao imperador Teodorico, é venerado como beato em algumas localidades italianas.

Homem de extrema erudição e educação filosófica sólida, Boécio conheceu, além de Platão e Aristóteles, o pensamento neoplatônico, fundamentalmente de Proclo e Plotino, o estoicismo, Orígenes e Agostinho, entre outros.

A obra testamento escrita por Boécio na prisão, de extrema peculiaridade no período patrístico, foi escrita por um cristão que, como já dissemos, não cita uma única passagem da Bíblia, muito menos santos da Igreja. Busca, contrariamente, o 
consolo e a felicidade nos filósofos pagãos da antiga Grécia, valendo-se, por vezes, de sua mitologia.

Necessitamos aqui realizar breve digressão e evidenciar alguns pressupostos fundamentais para o entendimento geral da Consolação escrita por Boécio, uma vez que não iremos nos ater à explicação minuciosa de conceitos apresentados na obra, pelos motivos acima citados. Nosso objetivo é demonstrar de que modo os conceitos que agora serão aqui elencados se relacionam com as fontes ocultas do Livro Sagrado na Consolação da Filosofia de Boécio.

Há um conceito central na obra que está no cerne daquilo que aqui queremos mostrar: é o conceito de 'felicidade'. No livro III de seu DCP, Boécio dedica algumas prosas (prosas 3 a 7) no esforço de tentar vincular a felicidade aos bens da Fortuna. ${ }^{2}$ Na prosa 8, entretanto, apresenta-se uma espécie de resumo daquilo que é tratado nas demais prosas acima citadas. Boécio procura demonstrar passo a passo o quanto os bens do mundo são insuficientes para proporcionar a plena felicidade. Juntar riquezas está associado a tornar alguém pobre, buscar honrarias equivale a humilharse perante aqueles que as concedem, deter o poder equivale a sempre correr o risco de traição e estar sujeito a inúmeros perigos. Do mesmo modo a glória constitui-se num caminho perigoso e difícil, a vida de prazeres torna desprezível aquele que para eles se entrega, pois iguala-se aos animais. A beleza física, igualmente efêmera, nos faz ver apenas as aparências, mas até mesmo Alcebíades tornar-se-ia feio, caso pudéssemos ver suas vísceras. Todos os bens da Fortuna, portanto, não garantem a felicidade que prometem, pois não reúnem a totalidade dos bens existentes. Estes bens (os bens da Fortuna) causam dispersão, cisão, e a verdadeira felicidade levanos à unidade e não à dispersão. ${ }^{3}$ Na prosa 8 do livro III do DCP, após Boécio objetar um a um os bens da Fortuna, mostrando o quanto eles são incompletos, encerra-se a prosa com esta passagem de extrema valia, para compreendermos a ausência da verdadeira felicidade nos bens da Fortuna:

\footnotetext{
2. “Todavia, o trabalho de Boécio consistirá em mostrar que esses bens, imagens da felicidade, não constituem o bem supremo, isto é, não podem proporcionar a posse do bem que todos naturalmente desejam; eles próprios, os múltiplos bens, hão de exigir a superação de si mesmos, em função de se exigir o bem que pode ser identificado com a felicidade verdadeira." (SAVIAN FILHO, 2005, p. 112 e 113).

3. "A felicidade não pode encontrar-se em algo fraccionado e múltiplo, mas num bem único, que não provém de coisas exteriores, e que encerra em si a plenitude de tudo o que se possa desejar." (DE BONI, 2003. p. 61). Vale também ressaltar os argumentos de Ghisalberti, que defendem uma linha de raciocínio semelhante aos argumentos aqui defendidos: "non è la quantità dei beni chiamati a soddisfare particolare aspirazioni dell'uomo, bensì la qualità. Un solo bene, purché sia vero e perfetto, può esaurire l'aspirazione alla felicità: è necessario recuperare compositivamente cio che "simplex est indiuisumque natura", perché la resolutio non si è mostrata altro che un error, che per Boezio há frazionato ciò che è semplice e indiviso per natura e, da vero e perfetto, l'ha trasformato in falso e imperfetto. Vero e perfetto è perciò quel bene chevè solo bene, tutto il bene, in grado di espungere da sé il suo contrario." (GHISALBERTI, 1981, p. 183-184).
} 
De tudo o que foi dito pode-se concluir como fato essencial que os atrativos incapazes de garantir os bens que prometem e que não reúnem em si a totalidade dos bens existentes não são caminhos que levam à felicidade, e portanto, não são suficientes para levar o homem à verdadeira felicidade. (Boeth. Cons. III, prosa 8, 28-32) .

Ao se mostrar tão enfático e convicto quanto ao que a felicidade não é, ou quanto àquilo que a felicidade plena efetivamente não é, o sábio romano percorre um itinerário para definir e conceituar o que é a felicidade perfeita, isenta de males, uma vez que, como demonstra a musa Filosofia a seu discípulo, a felicidade perfeita e completa não se encontra nos inconstantes bens da Fortuna.

Neste ponto, o diálogo é momentaneamente interrompido, e Boécio dirige uma prece ao divino arquiteto do universo, para que ilumine sua mente e lhe mostre o caminho para a luz, no intuito de poder encontrar a verdade. ${ }^{5}$ Numa das passagens mais famosas e belas da Consolação, Boécio reconhece Deus como princípio e finalidade de todas as coisas. ${ }^{6} \mathrm{~A}$ cosmogênese cantada por Boécio nesta passagem, torna esta poesia aquela que, sem sombra de dúvidas, é a mais conhecida e discutida em toda a obra do sábio romano escrita no cárcere. No início do poema, Boécio associa o ser divino a uma forma. ${ }^{7}$ Deus aqui é entoado como aquele que tudo governa e que independe de quaisquer causas externas:

Ó, tu, que governas o mundo com uma razão perpétua, / criador do céu e da terra, que do evo tiras o tempo, / e, permanecendo estável, moves tudo o que há, / a quem causas externas não ajudaram a plasmar / a matéria informe, mas a interna forma / do sumo bem, privada de toda inveja [...] (Boeth. Cons. III, IX, 1-6). ${ }^{8}$

\footnotetext{
4. Tradução de Willian Li.

5, No contexto desta prece, podemos recordar o que afirma Savian Filho em sua Introdução aos Escritos de Boécio (p. 50): "A concepção boeciana mostra-se, portanto, cristã, não neoplatônica, tampouco igual a do Timeu, embora revele vários pressupostos que remontam à elaboração platônicoaristotélica (imutabilidade, diferença entre substância divina e criada, eternidade etc.). Pode-se afirmar, por isso, em Boécio, um distanciamento da cosmologia platônica, pois, para ele, Deus fez o mundo por iniciativa própria e espontaneamente, contrariando a existência do demiurgo e dos deuses intermediários de Platão, e afirmando, na contrapartida que Deus produziu os céus e a terra "pelo Verbo", como diz a escritura em Jo 1,3; 1 Cor 8,6."

6. "A poesia IX do livro III é, talvez, uma das mais conhecidas e, certamente, a mais densa do De Consolatione. Pode ser lida como um texto que opera a transição do movimento argumentativo das prosas 3-9 para o movimento das prosas 10-12, pois não apenas canta a racionalidade com que se rege o mundo, aquela mesma para cuja contemplação convidava a prosa 8 , mas proclama, sem rodeios, adiantando o que se dirá na continuidade do texto, que Deus é o princípio de todas as coisas e, justamente como princípio, também é o fim de todas elas." (SAVIAN FILHO, 2005, p. 116).

7. "A Forma do sumo bem, inscrita na natureza divina e isenta de inveja." (SAVIAN FILHO, 2008, p. 229).

8. Tradução de Juvenal Savian Filho.
} 
Como vemos nesta passagem, a forma divina constitui o sumo bem. Boécio aprofundará e desenvolverá esta temática nas prosas 10-12. O canto de ação de graças conclui-se com um pedido:

Concede, ó Pai, à minha mente elevar-se à tua sublime morada, / concede que eu possa atravessar a fonte purificadora do bem / e, descoberta a luz, que eu possa fixar em ti os olhos atentos de meu espírito. / Dissolve as trevas e o peso de massa terrena e refulge em teu esplendor; / pois tu és serenidade, tu és o repouso tranquilo para os justos; / contemplar-te é o nosso fim; / tu que és, ao mesmo tempo, o princípio, o sustentáculo, o guia, o caminho e a meta. (Boeth. Cons. III, IX, 30-37).

A verdadeira felicidade é completa, pois encerra em si todos os bens, perfeita, pois se alguma das perfeições lhe faltasse não seria plena, e finalidade buscada por todos os homens. ${ }^{9}$ Uma pergunta, no entanto, faz-se presente: É possível encontrar um bem deste tipo neste mundo ou buscá-lo não passa de uma ilusão? Há, de fato, um bem tão supremo como este? Diz a musa Filosofia:

A esse respeito julgo ser necessário antes de tudo perguntarmos se um bem tal como o que acabamos de definir pode existir na realidade deste mundo; caso contrário, poderíamos passar ao lado da verdade sem vê-la e deixarmo-nos enganar por uma representação ilusória de nossa imaginação. (Boeth. Cons. III, X, 4-7). ${ }^{10}$

Ora, sabemos que este bem existe, pois tudo o que é imperfeito constitui uma degradação da perfeição. Vivemos num mundo cheio de imperfeições, e só podemos pensá-las e concebê-las se as compararmos com a própria perfeição. Se não admitirmos que a perfeição existe, não poderíamos sequer imaginar como aquilo que é imperfeito possa existir. Donde podemos inferir que, se constatamos a existência no mundo de uma felicidade que não é perfeita, necessariamente a felicidade perfeita existe de fato, não sendo uma quimera. Diz a Filosofia: "Mas se, como acabamos de demonstrar, há uma felicidade imperfeita que é um bem perecível, não se pode duvidar de que haja também uma felicidade durável e perfeita." (Boeth. Cons. II, X, 15-17).

Todos concordamos em afirmar que Deus, princípio de tudo, é bom. Deus, que possui o bem supremo, é a fonte de todos os bens. Sua existência se comprova pela noção de perfeição que temos em nós. Só sabemos que algo é mais ou menos perfeito porque o comparamos com a própria perfeição. Se a perfeição não existisse,

9. Importante ressaltar que no De Consolatione Philosophiae Boécio ora emprega o termo felicitas, ora emprega o termo beatitudo. Quanto à distinção, dentro da obra, destes dois termos, nos diz Savian Filho: “[...] ele (Boécio) parece distinguir o uso de felicitas, como um termo genérico para designar uma experiência de felicidade incompleta, exposta às variações da vida, e beatitudo, como sendo o estado perfeito de beatitude, da qual a felicitas seria uma espécie de antegozo e gozo imperfeito." (SAVIAN FILHO, 2005. p. 111).

10. Tradução de Willian Li. 
não poderíamos sequer pensar na existência de imperfeição. Para Boécio, o fato de o imperfeito existir comprova a existência da perfeição, pois se a perfeição não existisse, não poderíamos sequer imaginar a existência do imperfeito.

Deus, que é o princípio de todas as coisas, ao qual não podemos conceber nada melhor, (se um melhor existisse, ele é que deveria chamar-se Deus) possui o bem perfeito presente em si. ${ }^{11}$ Se outro algo possuísse o bem supremo e fosse anterior a ele, este é que seria Deus. É preciso admitir, portanto, que o Deus soberano contém o perfeito e soberano bem. $\mathrm{O}$ bem perfeito, ausente de males, é a felicidade, tendo em vista que nenhum mal pode atingi-lo. A verdadeira felicidade, então, reside em Deus. Entretanto, Deus não receberia a felicidade do exterior, pois ela está contida nele. ${ }^{12}$ Deus é a felicidade. ${ }^{13}$ Destarte, sendo idêntico à felicidade, Deus não pode têla recebido do exterior. Afirma a Filosofia:

11. Gostaríamos de lembrar que a leitura desta passagem do De Consolatione Philosophiae possui imensa semelhança com argumentos que encontramos, séculos depois, na chamada "prova racional da existência de Deus", de Anselmo de Aosta, onde o mesmo diz crer, com firmeza, que Deus é um ser do qual não é possível pensar nada maior. Cf. a respeito: ANSELMO, 1973, p. 108. Saranyana (2006. p.116) nos diz que "[...] Santo Anselmo devia ter à vista esta prova Boeciana da existência de Deus". Argumento com o qual Ghisalberti (1981, p. 186) parece concordar: "Ancora una volta il testo boeziano sollecita lo storico della filosofia: la definizione di Dio come "ciò di cui nulla può essere pensato di migliore" richiama la celebre definizione anselmiana del Proslógion, ma l'identità di definizione non importa un'identità di ragionamento." Ainda, sobre esta questão, nos diz Luca Obertello em sua Introdução à Consolazione della Filosofia ( $p$. 14): "Il bene sommo, poi, coincide con Dio stesso. Se Dio è quel di cui nulla può essere pensato di migliore, non potrà mai accadere che la bontà gli sia tolta. Nessuno dubita infatti che sia buono quello di cui nulla è migliore."

12. "Se ne deve concludere che la somma beatitudine coincide con la somma Divinità, e reside esclusivamente in essa." (OBERTELLO, 1996, p. 15). Saranyana (2006, p.116) nos diz: "Além disso, posto que Deus é perfeito, não só é feliz como é a própria felicidade."

13. Importantíssimo ressaltar aqui a semelhança do pensamento de Boécio com Agostinho de Hipona. Não é nosso objetivo neste trabalho, obviamente, comparar os dois filósofos. Convém, no entanto, uma pequena digressão sobre as semelhanças entre os dois autores. Na obra De Vita Beata (A Vida Feliz), Agostinho percorre um itinerário para investigar o que seja a felicidade, o qual procuraremos aqui mencionar os principais tópicos: a tese principal consiste em dizer que a vida feliz reside no perfeito conhecimento de Deus. Basicamente, o caminho percorrido por Agostinho na referida obra, e que aqui nos interessa, é o seguinte: os bens deste mundo são transitórios e mutáveis, perecíveis e passageiros. Para ser feliz, o homem precisa encontrar um bem permanente, livre das variações da sorte e das vicissitudes da vida. Sendo Deus eterno e imutável, quem possui Deus é feliz. (DVB $\mathrm{I}, 11)$. Pode, no entanto, ser feliz quem está à procura de Deus? Como Deus favorece àqueles que o procuram, é feliz também aquele que está à procura de Deus. A infelicidade está na carência ou na indigência. A maior e mais deplorável indigência é a privação de sabedoria, ao contrário, nada pode faltar a quem possui a sabedoria. Plenitude e indigência são termos opostos. Por plenitude Agostinho entende justa medida e proporção, onde não existe nem a mais e nem a menos do necessário. A sabedoria, portanto, é a medida da alma, pois ela é o contrário da estultícia (indigência). A sabedoria, diz Agostinho, é simplesmente a moderação do espírito, a justa medida. Digna deste nome é somente a sabedoria de Deus, por conseguinte, é feliz quem possui a Deus. A perfeita plenitude da alma consiste em conhecer perfeitamente: 1) por quem somos guiados até à Verdade (o Pai); 2) de qual verdade gozamos (o Filho); 3) por qual vínculo estamos unidos à Suma Medida (O Espírito Santo). Essa medida deve ser guardada e amada em toda parte, no nosso empenho em voltar a Deus. Este é, grosso modo, um resumo das ideias elencadas por Agostinho no DVB. (Valemo-nos aqui da edição brasileira: Solilóquios e A Vida Feliz. Tradução de Nair de Assis Oliveira. São Paulo: Paulus, 1998.) 
Não vás supor que o Pai de todas as coisas tenha recebido do exterior o soberano bem, que está contido nele ou que ele o possua devido à natureza, de tal forma que Deus e a felicidade, isto é, o possuidor e a coisa possuída, fossem substâncias distintas. (Boeth. Cons. III, X, 37-41).

Desta forma, o princípio de todas as coisas é o soberano bem, e como foi afirmado que o soberano bem e a felicidade são a mesma coisa, "é preciso admitir que Deus é a suprema felicidade" (Boeth. Cons. III, X, 55-56).

A partir destes pressupostos acima elencados, podemos agora afirmar algo relacionado às fontes ocultas da Bíblia na Consolação escrita por Boécio. O sábio romano, no início da obra, está desolado no cárcere e desacreditado diante da morte iminente. O desespero toma conta de sua alma, e pelo modo como a musa Filosofia o aborda, torna-se evidente que toda a obra é uma ascese de retorno à verdadeira morada. O sofrimento de Boécio é movido pelo esquecimento de sua verdadeira natureza, o que o leva à sensação de exílio, desterro. A Filosofia estabelece uma jornada ascética curativa a seu discípulo, que terá como critério para cura a lembrança daquilo que verdadeiramente é. Para tanto, é preciso reconhecer os falsos bens da Fortuna. Fama, riquezas, prazeres, honrarias: todos estes bens nos são dados e tirados pela Fortuna dentro da transitoriedade da vida. O erro humano, como vimos, consiste em buscar a felicidade nestes bens que não são permanentes. Há em Boécio, na Consolação, uma espécie de jornada ascética de retorno à compreensão da própria origem e de discernimento quanto à própria natureza. Jornada esta que foi ponto comum entre tantas escolas gregas e neoplatônicas. Vale lembrar precioso comentário num minucioso estudo feito sobre o ensino no período Patrístico e Escolástico (ULLMANN, 2000, p. 32):

\begin{abstract}
Os padres do deserto egípcio, na quarta centúria, acolhiam meninos e adolescentes, para, sob a direção de um venerado ancião, educá-los na ascese e na virtude. Incutiam-lhes uma formação mais espiritual que intelectual. Como educadores exímios, relevam São Pacômio (292- 342) e Santo Antônio de Tebas (251-356), ferrenhos opositores do orgulho intelectual dos gnósticos. Pacômio insistia em que seus discípulos soubessem de cor as Sagradas Escrituras, como fonte de alimento espiritual.
\end{abstract}

Como percebemos, este modo de educar vigente no período Patrístico, que visava a ascese e a virtude, lembra-nos os ensinamentos das escolas gregas, que também buscavam os mesmos princípios. Encontramos aqui outra significativa passagem:

Como podemos perceber, há imensa semelhança entre o pensamento de Boécio e Agostinho, no que se refere à tese de que o sumo bem e a autêntica felicidade residem em Deus. 
O neófito de Mitra devia ascender por uma escada de sete degraus, construídos cada um de um metal diferente. Orígenes, citando a Celso, dizia: 'O iniciado percorria os sete céus até o empíreo'. A Bíblia fala da escada de Jacó: 'Foi posta uma escada na terra e seu extremo superior alcançava o céu e os anjos de Deus subiam e desciam'. Os sociólogos encontraram essas concepções em culturas mui diversas. Jean Servier cita os indígenas Shipibo da Amazônia, que também tem noção da existência de uma escada entre o céu e a terra. Igualmente os peles vermelhas, em suas cerimônias iniciáticas, sobem nas árvores como a indicar uma subida que os leva ao céu. Noções parecidas encontram-se nos pigmeus da América central, na Austrália, e nas antigas culturas da Índia, Japão e Egito. (ALTESOR, 2000, p. 133-134 apud ULLMANN, 2002, p.136)

Além do ascetismo pertencente à obra, é importante evidenciar mais uma vez que, embora Boécio não cite uma única passagem da Bíblia em toda a Consolação, ressaltamos que podemos enxergar a obra como uma grande metáfora daqui que Jesus expressa no evangelho de João (18:36): “Respondeu Jesus: o meu reino não é deste mundo; se o meu reino fosse deste mundo, pelejariam os meus servos, para que eu não fosse entregue aos judeus; mas agora o meu reino não é daqui." Ora, em Boécio, como vimos, a felicidade também não está aqui, tampouco a verdadeira vida ou o verdadeiro reino. Além disso, há passagens evidentes do DCP que apresentam a Bíblia como fonte "oculta", e que não devem ser ignoradas. Podemos citar como exemplo, no De Consolatione Philosophiae: livro II, canto 4, onde Boécio afirma: “Foge dos perigos dissimulados em locais deslumbrantes. / Não te esqueças de construir tua casa sobre a pedra sólida", percebemos que esta passagem possui extrema semelhança com o evangelho de Mateus (7:24), sendo praticamente equivalente: "Todo aquele, pois, que escuta estas minhas palavras, e as pratica, assemelhá-lo-ei ao homem prudente, que edificou a sua casa sobre a rocha."

Importante também ressaltar que Boécio deteu-se com veemência ao trabalho voltado aos escritos teológicos que, embora não analisados no presente artigo, não podem ser ignorados para compreendermos o sentido histórico e intelectual no qual estava inserido o autor. Ressaltaremos uma passagem do De Fide Catholica onde Boécio explicita seu cristianismo:

A natureza divina, permanecendo, desde sempre e para sempre, sem nenhuma mudança, quis, espontaneamente e por uma vontade conhecida somente dela mesma, fazer o mundo, e, como ela não fosse absolutamente nada, ela fez que ele fosse. No entanto, não o tirou de sua própria substância, para que não se cresse divino por natureza, nem o fabricou de algo externo, para que não parecesse algo a ajudar a vontade divina, por uma natureza da existência independente, tampouco algo que não houvesse sido feito por Deus e, ainda assim, fosse. Ao contrário, pelo Verbo, Deus produziu os céus e criou a terra, de tal modo que fez, na celeste habitação, naturezas dignas do céu, e, para a terra, compôs o que é terreno. (Boeth. Fi. $52-64){ }^{14}$

14. Tradução de Juvenal Savian Filho. (grifos nossos). 
Como vemos no De Fide Catholica, Boécio enfatiza seu cristianismo e demonstra ver em Deus princípio e finalidade de todas as coisas, como também explicita no De Consolatione Philosophiae. Podemos afirmar que, embora Boécio não tenha citado em toda a Consolação uma única passagem da Bíblia, esta é uma fortíssima "fonte oculta" da obra consolatória do sábio romano, pois o mesmo se dá conta, ao longo da obra, que é preciso voltar-se primeiramente para Deus e para sua justiça ${ }^{15}$, a felicidade vem por acréscimo, com a participação Naquele que tudo rege. Além disso, pode-se também estabelecer um paralelo entre a busca da felicidade nos bens da Fortuna com o livro de Eclesiastes, onde se constata que toda esta busca é vaidade e correr atrás do vento. ${ }^{16} \mathrm{~A}$ felicidade reside em Deus. É preciso ser partícipe da divindade, nos diz Boécio na Consolação, assim como o evangelho de João afirma: "Eu e o pai somos um." ${ }^{17}$ Se os bens da Fortuna não fazem o homem feliz, e a verdadeira felicidade consiste em ascender à Deus, como bem evidenciou o sábio romano; ao ler a Consolação parece-nos ecoar em nossas mentes as palavras do Cristo no Evangelho de João (18:36) como sendo de fato o grande sentido Bíblico que serve de pano de fundo à obra de Boécio: "Meu reino não é deste mundo." ${ }^{18} \mathrm{O}$ sábio romano bem compreendeu que os bens da Fortuna estão sujeitos à vicissitudes da vida, à permanente inconstância. Boécio esteve sim imbuído de forte estoicismo em seu caminho ao consolo diante dos inúmeros reveses que lhe foram impingidos. No entanto, uma leitura atenta da Consolação nos evidencia que, embora não haja nenhuma citação direta do Livro Sagrado, o modo como Boécio se refere aos bens da Fortuna e a busca por uma felicidade sem máculas, caracteriza o cabedal intelectual de um homem profundamente erudito que preferiu fazer menção aos Antigos, mas que, como convicto cristão que era, possuía gravadas em seu coração as palavras que o Cristo profere no evangelho de Mateus (6: 19, 20): "Não acumuleis para vós outros tesouros na terra, onde a traça e a ferrugem destroem, e onde ladrões arrombam para roubar. Mas ajuntai para vós outros tesouros no céu, onde a traça nem a ferrugem podem destruir, e onde os ladrões não arrombam e roubam."

O legado da Filosofia concedido a Boécio foi justamente este: despertá-lo da letargia e reconduzi-lo à verdadeira morada: caminhando para seu interior e para Aquele que tudo rege. Uma leitura atenta e criteriosa da Consolação evidencia o Livro Sagrado como fonte oculta, mas para isso, no entanto, faz-se necessário ter olhos para ver, ouvidos para ouvir.

15. Vide evangelho de Mateus 6: 33: "Buscai, pois, em primeiro lugar, seu reino e a sua justiça, e todas estas cousas vos serão acrescentadas."

16. Cf. Eclesiastes 4: 16.

17. Cf. João 10: 30.

18. Cf. João 18, 36. 


\section{REFERÊNCIAS BIBLIOGRÁFICAS}

A BÍBLIA SAGRADA. Tradução de João Ferreira de Almeida. Rio de Janeiro: Sociedade Bíblica do Brasil, 1960.

AGOSTINHO, S. Solilóquios e A Vida Feliz. Tradução de Nair de Assis Oliveira. São Paulo: Paulus, 1998.

ALTESOR, H. Dionísio, el místico. Buenos Aires: Ediciones Corregidor, 2000.

ANICII M. S BOËTHII. Consolazione della filosofia. Introduzione, note, apparati di Luca Obertello. Milano: Rusconi Libri, 1996.

A consolação da filosofia. Tradução de Willian Li. São Paulo: Martins Fontes, 1998.

. Escritos (Opuscula Sacra). Tradução, estudos introdutórios e notas de Juvenal Savian Filho. São Paulo: Martins Fontes, 2005.

ANSELMO, S. Proslógio. Tradução de Angelo Ricci. São Paulo: Abril, 1973.

DE BONI, L. A. De Abelardo a Lutero-Estudos sobre filosofia prática na Idade Média. Porto Alegre: Edipucrs, 2003.

GHISALBERTI, A. L'ascesa boeziana a Dio nel libro III della Consolatio. In: Atti del congresso internazionale di studi boeziani (a cura de Luca Obertello). Roma: Editrice Herder, 1981, pp. 183-189.

GILSON, Etienne. A filosofia na Idade Média. Tradução de Eduardo Brandão. São Paulo: Martins Fontes, 2001.

OBERTELLO, L. Atti del congresso internazionale di studi boeziani. Roma, Herder, 1981. . L'universo boeziano. In: Atti del congresso internazionale di studi boeziani. Roma, Herder, 1981, (a cura de Luca Obertello), pp. 157-168.

. Introduzione. In: ANICII M. S BOËTHII. Consolazione della filosofia. Milano: Rusconi Libri, 1996.

SARANYANA, J. I. A Filosofia Medieval. Tradução de Fernando Salles. São Paulo: Instituto Brasileiro de Filosofia e Ciência "Raimundo Lúlio", 2006.

SAVIAN FILHO, J. Boécio e a ética eudaimonista. In: Cadernos de ética e Filosofia política 7. São Paulo: Produção USP, 2005. pp. 109-127. 
Estranhamento do mundo, cosmologia e ética: em torno de uma poesia de Boécio. In: Revista de Filosofia Unisinos, vol. 9. São Leopoldo, 2008, pp. 09-18. . Metafísica do ser em Boécio. São Paulo: Loyola, 2008.

ULLMANN, R. A. A universidade medieval. Porto Alegre: Edipucrs, 2000. . Plotino. Um estudo das Enéadas. Porto Alegre: Edipucrs, 2002. 